CASE Reports

\title{
Social harmonization and labor market performance in Europe
}

Katarzyna Mirecka Izabela Styczyńska

No 487 (2017) 
The views and opinions expressed here reflect the author(s) point of view and are not necessarily shared by the Nordic Council of Ministers, or CASE Network.

This report was prepared within a research project entitled "SocialBoost - effective measures of social harmonization as a boost for employability in times of demographic changes", which received funding under the Nordic Council of Ministers' Programme for NGOs in the Baltic Sea Region.

\section{Keywords:}

employment of the elderly, minimum wage, social security contributions, labor tax, Social Europe

\section{JEL Codes:}

J31, J32, C23, J38, J41, J61, H53, H55

"CASE Reports" is a continuation of "CASE Network Studies \& Analyses" series.

(c) CASE - Center for Social and Economic Research, Warsaw, 2017

\section{Graphic Design:}

Katarzyna Godyń-Skoczylas | grafo-mania

EAN: 9788371786518

\section{Publisher:}

CASE - Center for Social and Economic Research on behalf of CASE Network al. Jana Pawla II 61, office 212, 01-031 Warsaw, Poland tel.: (48 22) 20629 00, 82861 33, fax: (48 22) 2062901

e-mail: case@case-research.eu

www.case-research.eu 


\section{Table of Contents}

Authors......................................................... 6

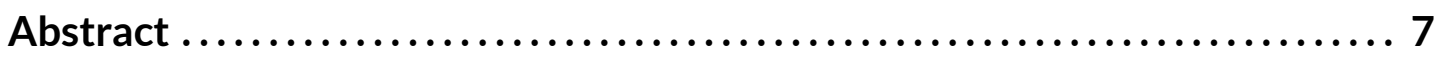

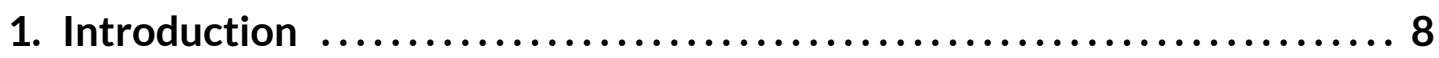

2. European Social Model ..................................... 11

3. Setting the context of social harmonization..................... 16

4. Methodology ............................................. 19

4.1. Econometric model ............................ 19

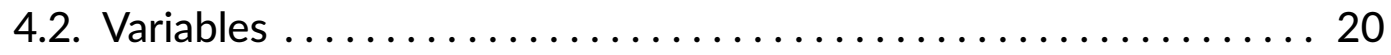

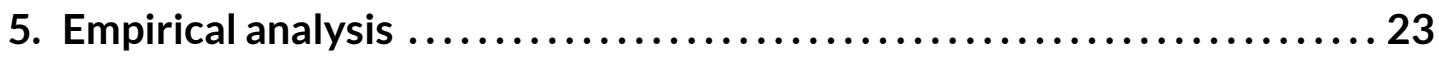

5.1. Overview of labor market performance in the European Union . . 23

5.2. Relationship between social harmonization and labor market performance..................... 24

6. Conclusions and policy recommendations ..................... 29

References ................................................ 31

Annexes .................................................... 36 
List of Tables and figures

Table 1: Definitions of dependent variables ................... 21

Table 2: Descriptions of explanatory variables $\ldots \ldots \ldots \ldots \ldots \ldots \ldots, 22$

Table 3: Definitions of variables ........................... 22

Table 4: Estimation results (population aged $15-64) \ldots \ldots \ldots \ldots \ldots . \ldots 26$

Table 5: Estimation results (population aged $50-64) \ldots \ldots \ldots \ldots \ldots 27$ 
List of Tables in Annex 1

Table A1: Minimum wages in the EU . . .36

Table A2: Unemployment rate, inactive population, and employment rate for the population aged 15-64 and 50+, 2015

List of Charts in Annex 2

Chart A1: Tax wedge in EU/OECD countries, 2015 (total, \% of labor costs) 38 Chart A2: Tax wedge level (as \% of total labor cost) on low-wage earners (i.e. single persons without children earning $67 \%$ of the average wage), 2015 .38

Chart A3: Ratio of minimum relative to average wages of full-time workers, 2015 39

Chart A4: Median gross hourly earnings and purchasing power standard, all employees (excluding apprentices), 2014 39

Chart A5: Expenditure on social protection in purchasing power standard

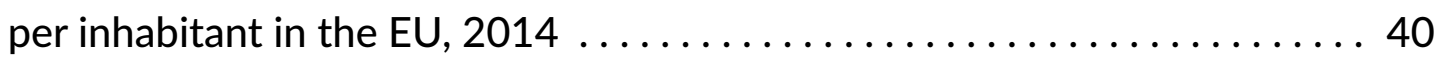

Chart A6: Expenditure on social protection as a \% of GDP, 2014 ....... 41

Chart A7: Total receipts from taxes and social contributions (including imputed social contributions) after deduction of amounts assessed but unlikely to be collected, 2015 


\section{Authors}

Katarzyna Mirecka is an economist at Center for Social and Economic Research (CASE) in Warsaw, specializing in subjects concerning social development issues. She graduated from Université Stendhal Grenoble III (France) and Poznań University of Economics (Poland). Katarzyna gained her first experience while working as a project manager for a Brussels-based NGO. At CASE she has broaden her experience in policy research, conducting interviews, data collecting and analyzing while writing applications and working in numerous projects for Polish and European institutions. Currently she acts as an expert in the project about enhancing CSOs contribution to evidence-based policy making for vulnerable groups in Belarus and Visegrad countries.

Izabela Styczyńska, PhD, is a researcher and expert in issues such as the labor market, social policy, and employment and is the Vice-President of the CASE Management Board. She obtained her PhD from the University of Turin in 2011. She holds a Master's degree in Economics from Warsaw University and a Master's degree in economics from CORIPE Piemonte in Turin. She has cooperated with CASE since 2005, participating in its numerous Polish and international projects. She is the author of publications in the fields of labor economics, social policy and health economics. 


\section{Abstract}

The paper aims to assess the impact of selected elements of social harmonization on labor market performance in the European Union among two groups of workers - the total working population and the elderly. The aim is to examine whether upward changes in labor taxes affect employment, unemployment, and inactivity rates in the European Union. The descriptive empirical evidence shows that the level of labor taxation varies significantly across European countries and the introduced changes might affect national markets differently. The Arellano-Bond dynamic panel data regression shows that an increase in the tax wedge, as an element of a social harmonization process, has a very weak impact on labor market performance in the European Union. The impact is statistically significant and negative only for the elderly (i.e. the population aged 50+). Empirical analysis suggests that upward social convergence might negatively affect the employment of the most disfavored groups in the labor market, such as the elderly. It suggests that social harmonization focused on reducing the tax wedge would have favorable effects on labor market performance, especially among the most disadvantaged groups. 


\section{Introduction}

Documents such as the Treaty establishing the European Community and the European Union (EU) Charter of Fundamental Rights set down fundamental social objectives, such as the promotion of employment and social protection, and include principles such as freedom, equality and solidarity, the right to fair and just working conditions, as well as social security and social assistance and equality between men and women.

During the last two decades, these social objectives have evolved, taking the form of the concept of a "Social Europe," which aims to introduce social harmonization within the EU. Social harmonization, which is an issue that has not been clarified for a significant period of time, is nowadays built on such elements as cohesion in social security contributions (SSC), personal income taxes (PIT), and "equal pay for equal work" among EU countries. Therefore, the concept is strongly related to labor taxation in European countries, as well as to the labor market policies affecting labor market performance and different working groups.

The impact of labor taxation on labor market performance has been the subject of numerous studies in recent years. The impact of the "tax wedge" - the difference between the real labor cost and the salary an employee receives in her bank account - on employment has also been broadly evaluated. The tax wedge consists of PIT, employer and employee SSC, and payroll taxes. Depending on the environment the individual operates in, diverse elements of the tax wedge have different distortionary effects on the economy. In a perfectly competitive labor market, only the total tax wedge is important. Regardless of which element of the labor tax is changed, the impact of taxation weakens labor market performance. When the labor market is imperfectly competitive, the composition of the tax wedge becomes relevant, and changes in the various labor taxes can affect the labor market performance differently. Therefore, it is extremely relevant to examine what elements of the tax wedge would be affected by upward social harmonization, as well as how they would influence labor market performance.

Labor market supply elasticity determines how the impact of a tax change is distributed over employment, unemployment, or inactivity. If labor-supply elasticity is large, labor market outcomes move significantly. Empirical studies show that labor supply elasticity 
is different for different groups of people. For example, it has been found that the low-skilled, females, and the elderly are the groups that are particularly responsive to changes in taxes and transfers. ${ }^{1}$

In addition, in recent years, tax policy analysts created a ranking of taxes according to their distortionary effect on economic performance in light of the evolving globalization processes. The least distortive taxes are taxes on immobile property, followed by consumption taxes, PIT, and corporate income taxes. ${ }^{2}$ The ranking confirms that with the open economy and the process of globalization, the ease of changing locations affects the distortion. The ease of changing locations for firms makes the corporate tax very volatile and responsive to tax competition among countries. PIT is less mobile, but legislation like the Directive of Posted Workers give some freedom to optimize it. Consumption taxes are less responsive to competition, whereas immobile property is affected the least by globalization.

After the recent global financial crisis, the EU and EU countries attempted to design tax systems that effectively respond to the abovementioned volatility. The aims of the changes are to create taxes that have a positive impact on a country's economy, public finances, growth, employment, and competitiveness. ${ }^{3}$ Therefore, current discussions on policy in this area are focusing on identifying appropriate ways to shift some of the tax burden away from labor and on to other types of taxation that are typically less harmful to employment and growth, such as consumption, recurrent property, and environmental taxes. ${ }^{4}$ Upward social convergence, understood as an increase in SSC and PIT imposed on labor, seems to contradict research findings, policy recommendations, and European Commission actions. On the other hand, social harmonization might be a solution to decrease the distortionary effect of the labor tax caused by market openness and the free movement of people.

Therefore, at this point in time, it is extremely relevant to examine how the proposed changes might affect the performance of the European labor market. The focus of this study will be on people aged $50+$, as the aging of populations is one of the demographic challenges Europe has been facing in recent years. Many studies show that the elderly experience strong barriers in retaining employability with age,$^{5}$ and that their labor market supply-elasticity

\footnotetext{
1 Siebertova, Z. et al. (2013), McClelland, R., Mok, S. (2012), Vodopivec, M. (2004)

2 European Commission (2011)

3 DG TAXUD (2015)

4 DG TAXUD (2011)

5 MOPACT (2016)
} 
is large. ${ }^{6}$ As a result, special measures are being developed at the EU and country level to increase the attractiveness of this working group in national labor markets and to decrease the level of their inactivity. Therefore, the aim of this study is to examine how changes in certain elements of the national tax wedge caused by the implementation of upward social harmonization affect the employment, unemployment, and inactivity rates at the EU level in two groups: the total working population and those aged 50+.

Upward social harmonization, is this report, is defined as an increase in the PIT and SSC paid by the employer, the employee, and the self-employed, and an increase in the minimum wage. The methodology used for this study is the Arellano-Bond dynamic panel data regression on a sample of EU-27 countries over the 2000-2012 period. The database used is based on European Union Labour Force Survey (EU LFS) data merged with information on tax policies from the Labour Market Reform (LABREF) database and the United Nations Conference on Trade and Development (UNCTAD) database.

The main results of the study find that the impact of the defined taxes on the unemployment, employment, and inactivity rates are, in the majority of cases, statistically insignificant for the total working population. In cases when it is significant, the impact is weak. When analyzing the impact of changes in the PIT, SSC, or the increase of the minimum wage within the group of the elderly, the variables become statistically significant and, in addition, negatively affect labor market participation within this working group.

Changes in taxation, aimed to deliver the social harmonization of labor taxes, play a minor role in determining the outcomes of the labor market on the whole working population. They have a significant impact on specific groups of people, like the elderly, who are more at risk of being dismissed, or who are less interested in working once they have reached the retirement age.

Therefore, policy makers, when developing social harmonization within Europe, should pay special attention to the elderly and, in general, to the groups of people whose participation in the labor market strongly depends on their marginal tax rates.

The structure of the paper is as follows. Next, we present the European context of the study on social harmonization. The following chapter describes the methodology, its limitations, databases, variables used, and then, we describe the results of the model for the whole working population, as well as for people aged $50+$. The final chapter presents conclusions and policy recommendations.

6 NEUJOBS (2011) 


\section{European Social Model}

Documents such as the Treaty establishing the European Community and the EU Charter of Fundamental Rights set down fundamental social objectives such as the promotion of employment and social protection, and include principles such as freedom, equality and solidarity, the right to fair and just working conditions, as well as social security and social assistance and equality between men and women.

The Treaty on the EU established the European Employment Strategy (EES) aiming at creating more and better jobs in the EU, and now constitutes a part of the Europe 2020 growth strategy. The EU's role in social policy is to provide "openness and mobility with domestic social cohesion; it should support national welfare states on a systemic level in some of their key functions; it should guide the substantive development of national welfare states by indicating general social standards and objectives and organizing mutual learning processes, but leaving the ways and means to the Member States."

The EU founding fathers assumed that supranational economic cooperation could be a tool for establishing cohesion both between and within countries. However, as traditional frameworks are not fit for managing the current challenges, the EU needs to create a virtuous circle where both pan-European and national cohesion are enhanced, and "needs to support both convergence towards higher levels of prosperity and well-being across the member states and convergence towards more equality within the member states." ${ }^{8}$

The European Social Model was the first step towards realizing these goals and was a tool to cope with globalization and the economic reforms made at the expense of workers' rights. It addresses six areas: workers' rights and working conditions, social protection, labor market policy, public services, social dialogue, and social cohesion. More precisely, the European Social Model aims at the following outcomes: the achievement of employability, the improvement of education, the fight against poverty and social exclusion, new family policies, the achievement of gender equality, and active aging. Now, social harmonization is the next step. ${ }^{9}$

7 Vandenbroucke, F., Rinaldi, D. (2015)

8 Vandenbroucke, F., Rinaldi, D. (2015)

9 This section is the general context of the study http://www.case-research.eu/en/socialboost-effective-measures-of-social-harmonization-as-a-boost-for-employability-in-tim 
Social harmonization is a relevant issue for today, as phenomena such as labor migration, intra-EU mobility, and brain drain, which are closely linked to it, are increasing and generating significant social and economic concerns for European and national policy makers. Furthermore, the discussion is evolving quickly as recent events such as Brexit, the Greek crisis, and the rise of populism in some Member States are influencing views on the future of Europe, with many calling it a "European identity crisis."

Social harmonization has been the subject of intense debate for several years. The main argument against this concept is that there is the possibility of significant discrepancies between EU and national priorities in the adoption of common guidelines. In post-communist countries, this concept is subject to controversy and skepticism as it is associated with centrally-planned economic and social systems. After their accession to the EU, new Member States experienced strong economic growth, but after the Eurozone economic crisis, the convergence mechanism has slowed down considerably. ${ }^{10}$ Since then, there has been strong pressure on governments to introduce austerity policies: to reduce social spending and to increase savings. Additionally, some find that job security was weakened by increased market flexibility; however, since then, employment security has not been enhanced. ${ }^{11}$

Recently, there has been a new debate on the need for greater solidarity within Europe, as well as greater fiscal and social harmonization, to tackle the problem of social dumping and to improve the social well-being of European citizens. Documents such as Mobility Package Directive on Posted workers or the European Pillar of Social Rights, which are aimed at finding solutions to the current situation, have been issued and debated. Opinions differ widely, especially depending on the different stakeholders and their country of origin.

Given the increasing mobility across EU Member States, the topics of workers' rights, working conditions, and public services have been among the most important on the European agenda - the Labour Mobility Package was a part of the 2015 and 2016 Commission work programs. ${ }^{12}$ Labor mobility is considered as a necessary element of the Single Market to absorb asymmetric market shocks, and social integration is a good way to face economic crises (inclusive and dynamic labor markets, better skilled labor force, and interventionist social systems). Therefore, upward convergence is seen as a key element of the Economic and Monetary Union. The creation of a Mobility Package is

\footnotetext{
10 Vandenbroucke, F., Rinaldi, D. (2015)

11 Heyes, J., Hastings, T. (2016)

12 European Parliament (2016)
} 
seen as a tool to gather and express in a clear form all existing provision $\mathrm{s}^{13}$ as well as to contribute to a fairer and deeper Internal Market. ${ }^{14}$

One element of the Labour Mobility Package is a targeted review of the Posting of Workers Directive. The Directive, first introduced in 1996, was strengthened by the Enforcement Directive in 2014. On March 8, 2016, the European Commission announced a reform of the laws on the posting of workers and, since then, it has been discussed among Member States. The aim of the revision is to "facilitate the provision of services across borders within a climate of fair competition and respect for the rights of posted workers." ${ }^{15}$ Specifically, employers of posted workers are currently obliged to award them the minimum rate of pay, which leads to inequalities in the labor market, while under the Directive, a rule of "equal pay for equal work" would be introduced. Another change would be that if the duration of a posted worker's contract is more than 24 months, national labor laws must be applied. Finally, more attention will be paid to workers sent by temporary agencies, so as to apply the national rules of the hosting country to posted workers abroad. ${ }^{16}$

In 1996, when the Directive was first introduced, the EU was more homogenous, and finding common solutions was easier to achieve. ${ }^{17}$ The European Commission's current propositions have faced strong opposition from 11 Southern and Eastern European countries, who have asked for revisions by triggering the "yellow card" procedure. The main issue has been whether new rules concerning social and working conditions should be established at the EU level, or if the countries should address these matters at the national level. Researchers have shown that the EU should limit its actions to providing a framework and support to national welfare states, but leave the ways and means to the Member States. ${ }^{18}$ Employer organizations from new Member States believe that the posting of workers is a way to achieve social convergence in Europe, and only then will new Member States be able to provide more social benefits. In their view, the revised Directive will lead to a more divided Europe. Moreover, they claim that the assumptions cited in public debate are based

\footnotetext{
13 European Political Strategy Center (2015)

14 European Commission (2015a)

15 European Commission (2016)

16 Idem.

17 CEPS (2016)

18 Vandenbroucke, F., Rinaldi, D. (2015)
} 
on illegal practices. ${ }^{19}$ Not only are new Member States against the revision, but German business representatives also claim the Directive's revision goes against the Rome 1 Regulation regarding limitation of posting. ${ }^{20}$ There are concerns that the Directive would harm the Internal Market and deprive entrepreneurs of the possibility to benefit from price competition in the service sector. ${ }^{21}$ Yet, the European Commission decided that the principle of subsidiarity was not breached in the Directive and did not pursue the "yellow card" procedure.

However, this positive view about free movement is not shared by everyone: for instance, posted workers have been accused of fraud, abuse, and unfair competition. ${ }^{22}$ The "Polish plumber"-the skilled and cheap worker "stealing jobs from national workers" has become a symbol of this phenomenon in public debates. Radical views on European mobility are not rare: for example, French Presidential candidate Marine Le Pen pledged that, if elected, she would introduce a $10 \%$ tax on all contracts employing foreign workers. ${ }^{23}$

Despite integration-skeptical views, strong evidence in favor of more integration has been found by researchers. In order to cushion the country-specific shocks following the latest financial crisis, as well as to strengthen EU Single Market integration, more labor, goods, and investment mobility between EU countries is needed: labor mobility should be facilitated and administrative burdens levied. ${ }^{24}$ Even though freedom of movement is a very challenging right and needs complex and well-prepared policies, it is considered vital for the European Single Market. ${ }^{25}$ Introducing a more universal unemployment and pension system would lead to an improvement in the socio-economic situation of temporary workers; however, given the fiscal situation of most Member States, social expansion is impossible and, therefore, solutions cannot require any financial involvement. ${ }^{26}$ The new European Social Model must be financially as well as socially sustainable, which requires great care with its creation. The current situation is often considered as a crisis that can be overcome through the right adjustments.

\footnotetext{
19 Konfederacja Lewiatan (2016)

20 Euractiv (2016)

21 EUobserver (2016)

22 CEPS (2016)

23 Independent (2017)

$24 \operatorname{OECD}(2016)$

25 CEPS (2016)

26 Eichhorst, W. et al. (2016)
} 
European Commission President Jean-Claude Juncker, in his White Paper released on March 1, 2017, acknowledges that the European population and economy are both shrinking; therefore, Member States must work together even more now than before. The White Paper addresses the EU's current issues (e.g. the impact of new technologies on society and jobs, globalization, security concerns, and the rise of populism) and presents five different scenarios of the future of the Community. Its aim is to launch a debate about the future of Europe and the EC will contribute to it with reflection papers (among others, about developing the social dimension of Europe) in the months to come. ${ }^{27}$

27 EuVisions (2016) 


\section{Setting the context of social harmonization}

The conceptualization of social harmonization takes its origins from several forces, such as the recent changes in European legislation (Directive 96/71/EC of the European Parliament and of the Council of 16 December 1996 concerning the posting of workers in the context of provision of services); the debate on upward social convergence; 28 and the recent changes in the definition of the minimum wage.

The elements of social harmonization proposed for analyses are mainly based on the European Labour Mobility Package and, in particular, on the proposed changes in the Directive of Posted Workers. Due to data constraints, the availability of information, and methodological suitability, the following elements of social harmonization are considered in this study:

\section{European minimum wage;}

2. harmonization in SSC; and

3. harmonization in labor taxation.

\section{European minimum wage}

Estimating and building a European minimum wage is an extremely challenging process due to the complicated rules of this measure implemented at a national level. In European countries, the minimum wage is defined by various factors - notably, overall wage levels, cost of living, average and median income and earnings, the definition of the poverty line (the minimum wage should be above the poverty line), and the definition of low wages ( 50 or $60 \%$ of national average earnings) (see Table A1 in Annex 1).

Of the 28 Member States, 22 have a statutory/universal minimum wage (see Table A1 in Annex 1). In the EU countries that do not have a statutory minimum wage (Austria, Cyprus, Denmark, Finland, Italy, and Sweden), we find a wide coverage of collective bargaining and high trade union density (Denmark, Finland, and Sweden), as well as mandatory membership to employer associations, such as in Austria, or jurispruden-

28 Grand Duchy of Luxemburg (2015) 
tial practice, like in Italy. ${ }^{29}$ Table A1 of Annex 1 provides an overview of the differences in minimum wages in EU countries. All workers employed and exercising their profession on the territory of one of the 22 countries having implemented a minimum wage are entitled to it; however, Germany and France implemented specific policies in 2015 which have recently been subject to controversy.

In 2015, Germany introduced a minimum wage for all employees working in Germany, regardless of where their employer is registered. This new rule is relevant for the international transport, and international road transport sectors in particular, as it obliges all transporters for whom Germany is a country of transit to abide by the minimum wage rule. That same year, France decided to follow Germany's lead, but instead focused on the road and fluvial transport sectors, adopting a law according to which "any driver engaged in cabotage operations during international transport, will benefit from the social rules and the minimum wage in France. Foreign carriers, who work in France without providing the required certification, will be prosecuted for illegal work." ${ }^{30}$ France's law aims at tackling social dumping.

\section{Social security contributions}

Under EU regulations regarding the coordination of social security systems, a person residing in a country other than the one in which he or she was born is subject to the social security system of one country at a time. Combining the right to social security with freedom of movement for intra-EU migrants and posted workers has been one of the major concerns for EU Member States. To guarantee both principles, the EU thought it necessary to adopt social security measures which prevent EU citizens working and residing in a Member State other than their own from losing their social security rights. To illustrate this idea, a worker posted from Portugal or Poland to the Netherlands, earning the same net income, can save an employer up to $25 \%$ on labor costs through differences in social security payments. ${ }^{31}$

Therefore, an important debate is being raised on the issue of social dumping and the necessity to protect workers' rights and standards. ${ }^{32}$ This is one of the points addressed in the debate on social harmonization.

In response to this debate and postulates, we assume that social harmonization will set a European minimum rate for SSC, which would have to be imposed on salaries. Its precise rate will be assessed when creating the hypotheses.

\footnotetext{
29 DG for Employment, Social Affairs and Inclusion (2016)

30 Drive Europe News (2016)

31 European Trade Union (2016)

32 European Trade Union (2015)
} 


\section{Labor taxation}

A wide variation in the tax wedge exists between European countries. It ranges from somewhat below $20 \%$ in Malta to just over $50 \%$ in Belgium. Labor taxation is among the highest in Belgium, Hungary, France, Germany, and Italy (Chart A1 in Annex 2).

Such high differences between EU countries give employers an incentive to benefit from lower taxes being paid in different countries. This might be especially the case for specific social groups such as low-skilled/low-income earners or the elderly.

Despite that labor taxation is the sole responsibility of EU Member States, the debate about labor tax harmonization is taking place at different EU levels. For example, the very recent staff working document of the European Commission ${ }^{33}$ states that tax competition is being observed at the EU level due to globalization processes. It deeply affects mobile capital and might cause a capital outflow. As a solution, tax harmonization could be proposed as a relevant tool in fighting this phenomenon. Therefore, we presume that some changes in the harmonization of labor taxation would be recommended at the EU level for social harmonization purposes. Despite our lack of knowledge of the exact terms of the Labour Mobility Package, we are going to test the impact of harmonized labor taxation on European labor market performance, because we assume that a European minimum rate of labor tax imposed on labor will be proposed in the social harmonization project.

33 European Commission (2015b) 


\section{Methodology}

\subsection{Econometric model}

The aim of this study is to examine the effect of the implementation of upward social harmonization on labor market performance, measured by employment, unemployment, and participation rates at the European level. The model adopted in this study is based on diverse macroeconomic studies on this issue, ${ }^{34}$ and aims at assessing the impact of labor taxes on labor market outcomes in a cross-country perspective. ${ }^{35}$ We decided to employ the Arellano-Bond dynamic panel data regression model, which allows us to obtain a consistent generalized method of moments (GMM) estimator for the parameters of moment conditions in levels. The reasons for implementing this model are twofold. Firstly, this technique allows us to correct for the correlation between the unobserved panel-level effects and the lagged dependent variables. Secondly, previous empirical studies ${ }^{36}$ note that this is the best model to handle the difficulties regarding the identification of robust correlations between labor market performance and taxation policies, because of missing controls and of the possible endogeneity of policies and country-specific institutions.

Therefore, the regression model takes the following form:

$$
y t, i, j=\alpha i+y t+\beta S H t, i, j+\delta X t, i+\varepsilon t, i, j
$$

where $y$ is the employment, unemployment, and participation rates, respectively, in time $t$ and country $i . j$ stands for the specific subsample of the population (50+). $\mathrm{SH}$ is a dummy variable equal to one if an upward change in labor taxes has been implemented and is observed in year $t$, country $i$, and subsample $j . \alpha$ and $\gamma$ are, respectively, a time invariant country fixed effect and a time dummy, which accounts for the time effect common to all

34 Daveri, F., Tabellini, G. (2000), Vork, A. et al. (2007), Cristescu, A. et al. (2016)

35 Dolenc, P., Laporsek S. (2010)

36 European Commission (2011) 
countries. Xt, i includes time varying additional controls specified in a Table 2 below. The use of time and country fixed effects in the regression model partially copes with the misspecification problems discussed above.

We assumed that the tax variables have an impact up to two years after the reform. This allows for more flexibility in the detection of the impact, which can realistically be expected in a longer term. Thirdly, besides country fixed effects, year fixed effects are also introduced. This way, market cycles affecting all European countries in the same period are controlled for.

The regression specification was subject to several robustness checks and we confirmed that the results seem robust.

In this paper, we use annual data for 27 European countries ${ }^{37}$ for the period 2000-2012. ${ }^{38}$ The samples used include people aged 15-64 and people aged 50-64. The information about the changes in the tax systems was drawn and merged from the LABREF database. ${ }^{39}$ Information about trade and foreign direct investment (FDI) comes from the UNCTAD database. $^{40}$

\subsection{Variables}

The analysis focuses on the employment, unemployment, and participation rates for the whole population aged 15-64 and for the working group aged 50-64, separately. Three dependent variables are considered: firstly, unemployment rates, defined as the ratio between the number of unemployed and the sum of the unemployed and employed (derived from Eurostat statistics); secondly, the employment rate, defined as the number of employed over the total number of respondents; and thirdly, the inactivity rate, defined as the percentage of people who are outside the labor force over the total population. The same dependent variables are constructed for people aged $50+$ from Eurostat statistics. The definitions of the dependent variables are described in Table 1 below.

\footnotetext{
37 Croatia is excluded from the study due to a lack of data

38 Please note that data were missing for some European countries, such as Croatia, Bulgaria, and Romania. Data were approximated using Eurostat national statistics.

39 Data retrieved from the LABREF database

40 Data retrieved from the UNCTAD database
} 
Table 1: Definitions of dependent variables

$\begin{array}{ll}\text { DEPENDENT VARIABLE } & \text { DEFINITION } \\ \begin{array}{ll}\text { Unemployment rate } & \text { The ratio between the number of unemployed and the sum } \\ \text { of the unemployed and employed (according to the EU LFS database) }\end{array} \\ \begin{array}{ll}\text { Employment rate } & \text { The number of employed over the total number of respondents } \\ \text { Inactivity rate } & \text { The percentage of people who are outside of the labor force } \\ & \text { over the total population }\end{array}\end{array}$

The explanatory variables are presented in Table 2 below. As our approach consists of panel data macro-econometric analyses, we can include several macroeconomic factors that are specific to each country and which are assumed to affect labor market outcomes. We include: gross domestic product (GDP), FDI, trade openness, and inflation rate. According to the literature, GDP is expected to significantly and positively affect labor market outcomes. ${ }^{41}$ Inflation rate, on the other hand, is assumed to negatively affect the employment rate..$^{42}$ Globalization, which is approximated by the trade openness, might affect the labor market outcomes in an ambiguous manner. ${ }^{43}$ Nevertheless, it is a significant factor influencing labor market outcomes, and, furthermore, is a relevant factor affecting the discussion about social harmonization. Other country specific variables included in the study are: average age in a country, the proportion of people with a higher education, the proportion of the employed with a permanent contract, the proportion of immigrants, and the share of government expenditures as a percentage of GDP.

\footnotetext{
41 Seyfried, W. (2011), Andreica, M.E. et al. (2011)

42 Andreica, M.E. et al. (2010)

43 Dimian et al. (2013)
} 
Table 2: Definitions of explanatory variables

\begin{tabular}{|c|c|}
\hline EXPLANATORY VARIABLE & DEFINITION \\
\hline GDP & Real GDP per capita, in country $i$ at year $t$, euro per inhabitant \\
\hline FDI & $\begin{array}{l}\text { Inward FDI stock as a percentage of GDP (with GDP expressed as an index, } \\
\text { where } 2005=100 \text { ), in country } i \text { at year } t\end{array}$ \\
\hline Trade openness & $\begin{array}{l}\text { Trade openness indicators, measured as a percentage of GDP, } \\
\text { in country i at year } t\end{array}$ \\
\hline Inflation rate & Consumer price index (CPI) with the base year 2000 , in country $i$ at year $t$ \\
\hline Age & Average age in country $i$ and year $t$ \\
\hline Higher-education & Proportion of people with a higher education, in country $i$ at year $t$ \\
\hline Tenure & $\begin{array}{l}\text { Proportion of the employed with a permanent position, in country } \\
\text { i at year } t\end{array}$ \\
\hline Immigrants & Proportion of immigrants, in country i at year $\mathrm{t}$ \\
\hline Public & $\begin{array}{l}\text { Total general government expenditures as a percentage of GDP, in country } \\
\text { i at year } t\end{array}$ \\
\hline
\end{tabular}

Social harmonization is defined by three dummy variables: PIT, SSC, and a minimum wage. As we are discussing upward social convergence, the impact of an increase in all these measures is considered. Table 3 below presents how these variables were created and are included in the model. Our information was drawn from the LABREF and UNCTAD databases and merged with data from with the EU LFS and Eurostat databases.

Table 3: Definitions of variables

\begin{tabular}{ll} 
Variable & Definition \\
Increase of PIT & $=1$, if PIT has increased; $=0$, otherwise \\
\hline Increase of SSC & $=1$, if any element of SSC has changed and caused an increase of SSC \\
Increase of minimum wage & $=1$, if the minimum wage has increased
\end{tabular}




\section{Empirical analysis}

\subsection{Overview of labor market performance in the European Union}

There are large differences in the level of labor taxation among EU Member States, and this is a main reason behind the intense debate surrounding social harmonization in the age of globalization. According to the Organisation for Economic Co-operation and Development (OECD), the tax wedge measures the extent to which tax on labor income discourages employment. ${ }^{44}$ Among EU/OECD countries in 2015, people working in Belgium, Germany, and France were subject to the highest tax levels, whereas those in Ireland, the UK, and Poland are taxed the least (see Chart A1 in Annex 2). Similarly, according to Eurostat, if we consider only low-wage earners, among all EU countries, they are taxed the most in Belgium, Hungary, Austria, and Germany. Tax wedge levels are the lowest in Malta, Ireland, the UK, and Luxembourg. (see Chart A2 in Annex 2).

There are also significant differences in the level of the minimum wage (Table A1 in Annex 1). Among the countries applying the minimum wage level in the EU in 2014 and 2015, the lowest wage levels are found in Bulgaria and Romania, followed by other CEE countries. France, Ireland, Germany, Belgium, and the Netherlands have almost equal levels of the minimum wage. The country with the highest minimum wage level is Luxembourg, both in 2014 and 2015. If we compare this data with the minimum relative to average wages of full-time workers ratio in EU/OECD countries, we notice the highest ratios in France, Slovenia, and Portugal, whereas the lowest can be found in Spain, the Czech Republic, and Estonia (see Chart A3 in Annex 2).

Regarding median hourly earnings, both in euro and in terms of the purchasing power standard (PPS), the countries with higher levels are Denmark, Luxembourg, and Ireland. By contrast, we observe lower levels in Bulgaria, Romania, Latvia, Lithuania, Slovakia, Estonia, Poland, and Slovenia (see Chart A4 in Annex 2).

Expenditures on social protection per inhabitant in absolute values in CEE countries are the lowest among the EU. Countries that spend the most on social protection per 
person are Austria, the Netherlands, Luxembourg, France, Germany, and Denmark (see Chart A5 in Annex 2). Likewise, if we take into consideration the percentage of GDP spent on social protection by country in 2014 , more or less, the same countries spent the most: France, Denmark, Finland, the Netherlands, and Belgium (above the EU-28 average). At the end of this list, we find Latvia, Lithuania, Romania, and Bulgaria (see Chart A6 in Annex 2).

Although there are no big gaps among Member States, we clearly see that employment levels are the highest in countries with high minimum wages or with no minimum wage at all: Sweden, the Netherlands, Germany, and Denmark. We also observe here a surprisingly high score for the Czech Republic. However, regarding unemployment, the gaps are much more significant: the highest unemployment can be found in Greece and Spain in both age categories, followed by Portugal, Cyprus, Slovakia, and Finland. The situation is similar, but not the same, regarding inactivity rates, which are the highest in Malta, Romania, and Greece for the group of those aged 50+, but are also surprisingly high in Luxembourg. For people aged 15-64, it is Italy, Romania, and Croatia (Table A2 in Annex 1).

In summary, we can see that although in CEE countries, where labor taxation, social protection level per inhabitant, and minimum wage are usually lower than the EU average, labor market participation is also quite low (except for the Czech Republic). However, we cannot draw any conclusions from these observations as other factors may be influential, and it cannot be considered as a simple dependence. For instance, Spain and Greece have medium-level tax wedges, but both have higher levels of unemployment. Therefore, there may be no relation between these levels, and this is a conclusion that we will prove in the next section in our econometric analyses.

\subsection{Relationship between social harmonization and labor market performance}

The aim of this part of the report is to empirically examine the relationship between upward social convergence and labor market outcomes. The first part of this subchapter presents the results for the whole population, and the second subchapter concentrates on those aged $50+$.

The whole population. The main results of the econometric analyses confirm that GDP has the greatest impact on labor market outcomes, confirming the economic theory on the direct link between macroeconomic output and level of employment (see Table 4 below). An increase in GDP per capita by one euro per inhabitant increases the over- 
all employment rate by over $4 \%$. When GDP per capita increases, the unemployment rate decreases by about $3 \%$. Trade openness seems to have a positive, but weak impact on employment rate, while it is statistically insignificant for the unemployment rate and inactivity rate. Also, the inflow of FDI seems to have very little impact on the employment rate, and no statistical significance for other labor market characteristics. The proportion of people with higher education is statistically significant, and as expected, increases the employment rate and inactivity rate and decreases the country unemployment rate. Other variables describing country-specific characteristics are statistically insignificant and their impact seems to be negligible.

Variables approximating the implementation of upward social harmonization at the EU level seem to be statistically insignificant, and, if significant, the impact is relatively low. An increase in SSC, PIT, or the minimum wage seems to affect the employment rate very weakly in a negative way, whereas it has no statistical significance for the unemployment or inactivity rate. It also appears that the impact is observed in the second and the third year after the implementation of the change, and not earlier.

\begin{tabular}{lccc} 
Variable & Unemployment rate & Employment rate & Inactivity rate \\
Unemployment rate (t-1)/ & 0.712 & 0.728 & 0.722 \\
Employment rate (t-1)/ & $(10.48)^{* * *}$ & $(9.79)^{* * *}$ & $(9.57)^{* * *}$ \\
Inactivity rate (t-1) & & & \\
SSC-increase & 0.001 & 0.000 & 0.001 \\
& $(0.65)$ & $(0.15)$ & $(0.78)$ \\
\hline SSC-increase (t-1) & 0.000 & -0.001 & 0.003 \\
& $(0.20)$ & $(0.61)^{*}$ & $(1.38)$ \\
SSC-increase (t-2) & 0.002 & -0.002 & 0.001 \\
& $(1.09)^{*}$ & $(0.95)^{*}$ & $(1.31)$ \\
\hline PIT-increase & 0.001 & -0.001 & 0.001 \\
& $(1.84)$ & $(1.99)^{*}$ & $(0.02)$ \\
\hline PIT-increase (t-1) & 0.000 & -0.000 & 0.002 \\
& $(0.41)$ & $(0.1)$ & $(0.95)$ \\
\hline PIT-increase (t-2) & 0.001 & -0.002 & 0.000 \\
& $(2.53)^{*}$ & $(1.16)$ & $(0.29)$ \\
Min. wage-increase & 0.001 & -0.003 & 0.003 \\
& $(0.43)$ & $(1.29)^{*}$ & $(1.79)^{*}$ \\
Min. wage-increase (t-1) & 0.003 & -0.002 & 0.002 \\
& $(0.11)^{*}$ & $(0.57)$ & $(0.94)^{*}$ \\
Min. wage-increase (t-2) & 0.002 & -0.000 & 0.000 \\
& $(1.29)^{*}$ & $(0.48)$ & $(1.68)$ \\
\hline GDP & -0.030 & 0.044 & -0.071 \\
& $(0.41)^{* *}$ & $(3.69)^{* *}$ & $(1.19)$ \\
\hline Trade openness & -0.021 & $0.017^{*}$ & -0.021 \\
& $(0.74)$ & $(0.087)$ & $(0.035)$ \\
\hline
\end{tabular}


Table 4: Estimation results (population aged 15-64)

\begin{tabular}{lccc} 
Variable & Unemployment rate & Employment rate & Inactivity rate \\
FDI & 0.029 & $0.011^{*}$ & 0.001 \\
Inflation rate & $(0.094)$ & $(0.01)$ & $(0.18)$ \\
& 0.000 & $-0.022^{*}$ & 0.001 \\
Higher-education & $(0.121)$ & $(0.172)$ & $(0.001)$ \\
& -0.073 & 0.052 & -0.031 \\
Tenure & $(1.97)^{* *}$ & $(1.99)^{*}$ & $(2.36)^{* *}$ \\
\hline Immigrants & 0.118 & -0.011 & -0.068 \\
& $(1.87)$ & $(0.23)$ & $(0.98)$ \\
Public & -0.025 & -0.021 & 0.027 \\
& $(1.92)$ & $(0.45)^{*}$ & $(2.16)^{*}$ \\
& 0.001 & -0.001 & -0.000 \\
\end{tabular}

Robust z-statistics in parentheses; ${ }^{* * *}$ significant at the $1 \%$ level; ${ }^{* *}$ significant at the $5 \%$ level; * significant at the $10 \%$ level; (no star) statistically insignificant

Population aged 50+. Overall, the estimation results from the sample of people aged 50-64 reveal that this group is more reactive to macroeconomic and fiscal changes (see Table 5). Similar to the estimations on the whole population, the higher the GDP, which approximates economic well-being in a country, the higher the employment rate and the lower the unemployment rate for those aged 50-64. Interestingly, labor market performance for the population aged $50+$ is slightly less responsive to GDP changes when compared to the total population. The results are in line with other research findings showing that in times of crisis, the elderly are not the group of people with the highest risk of being dismissed..$^{45}$

45 The reason behind this is the difficult situation of the young population in the labor market (i.e. zero-hour contracts and insecure situation in the labor market, among others). For more information, see the FP7 STYLE project: http://www.style-research.eu/ 
Table 5: Estimation results (population aged 50-64)

\begin{tabular}{|c|c|c|c|}
\hline Variable & Unemployment rate & Employment rate & Inactivity rate \\
\hline $\begin{array}{l}\text { Unemployment rate }(\mathrm{t}-1) / \\
\text { Employment rate }(\mathrm{t}-1) / \\
\text { Inactivity rate }(\mathrm{t}-1)\end{array}$ & $\begin{array}{c}0.829 \\
(17.76)^{* * *}\end{array}$ & $\begin{array}{c}0.833 \\
(9.30)^{* * *}\end{array}$ & $\begin{array}{c}0.620 \\
(6.69)^{* * *}\end{array}$ \\
\hline SSC-increase & $\begin{array}{c}0.001 \\
(0.76)^{* *}\end{array}$ & $\begin{array}{l}-0.008 \\
(0.17)^{*}\end{array}$ & $\begin{array}{c}0.001 \\
(0.45)^{* *}\end{array}$ \\
\hline SSC-increase (t-1) & $\begin{array}{c}0.001 \\
(0.20)^{*}\end{array}$ & $\begin{array}{l}-0.002 \\
(0.61)^{*}\end{array}$ & $\begin{array}{l}0.002 \\
(1.38)\end{array}$ \\
\hline SSC-increase (t-2) & $\begin{array}{c}0.003 \\
(0.89)^{*}\end{array}$ & $\begin{array}{l}-0.001 \\
(0.84)^{*}\end{array}$ & $\begin{array}{l}0.003 \\
(1.04)\end{array}$ \\
\hline PIT-increase & $\begin{array}{c}0.005 \\
(1.07)^{* * *}\end{array}$ & $\begin{array}{c}-0.004 \\
(1.08)^{* *}\end{array}$ & $\begin{array}{l}0.007 \\
(0.53)^{*}\end{array}$ \\
\hline PIT-increase (t-1) & $\begin{array}{c}0.002 \\
(0.38)^{*}\end{array}$ & $\begin{array}{l}-0.001 \\
(0.74)^{*}\end{array}$ & $\begin{array}{l}0.002 \\
(0.78)\end{array}$ \\
\hline PIT-increase (t-2) & $\begin{array}{c}0.003 \\
(1.76)^{*}\end{array}$ & $\begin{array}{c}-0.002 \\
(1.16)\end{array}$ & $\begin{array}{l}0.000 \\
(0.29)\end{array}$ \\
\hline Min. wage-increase & $\begin{array}{l}0.000 \\
(2.47)\end{array}$ & $\begin{array}{c}-0.001 \\
(1.71)\end{array}$ & $\begin{array}{l}0.002 \\
(1.67)\end{array}$ \\
\hline Min. wage-increase (t-1) & $\begin{array}{l}0.000 \\
(0.11)\end{array}$ & $\begin{array}{c}-0.003 \\
(1.34)\end{array}$ & $\begin{array}{l}0.003 \\
(0.82)\end{array}$ \\
\hline Min. wage-increase (t-2) & $\begin{array}{l}0.000 \\
(1.42)\end{array}$ & $\begin{array}{c}-0.000 \\
(0.28)\end{array}$ & $\begin{array}{l}0.000 \\
(0.98)\end{array}$ \\
\hline GDP & $\begin{array}{c}-0.021 \\
(0.41)^{* *}\end{array}$ & $\begin{array}{c}0.041 \\
(1.74)^{* *}\end{array}$ & $\begin{array}{l}0.000 \\
(1.81)\end{array}$ \\
\hline Trade openness & $\begin{array}{c}0.007 \\
(1.32)^{*}\end{array}$ & $\begin{array}{c}-0.032 \\
(1.08)^{* *}\end{array}$ & $\begin{array}{l}0.002 \\
(1.71)\end{array}$ \\
\hline FDI & $\begin{array}{c}0.005 \\
(0.91)^{*}\end{array}$ & $\begin{array}{l}-0.006 \\
(0.76)^{*}\end{array}$ & $\begin{array}{l}0.001 \\
(1.14)\end{array}$ \\
\hline Inflation rate & $\begin{array}{l}0.002 \\
(1.32)\end{array}$ & $\begin{array}{c}-0.002 \\
(1.03)\end{array}$ & $\begin{array}{l}0.000 \\
(0.98)\end{array}$ \\
\hline Higher-education & $\begin{array}{l}-0.031 \\
(1.47)^{*}\end{array}$ & $\begin{array}{c}0.081 \\
(1.72)^{* *}\end{array}$ & $\begin{array}{l}-0.042 \\
(1.76)^{* *}\end{array}$ \\
\hline Immigrants & $\begin{array}{c}-0.098^{*} \\
(1.35)\end{array}$ & $\begin{array}{l}0.125^{*} \\
(0.45)\end{array}$ & $\begin{array}{c}-0.038^{*} \\
(1.12)\end{array}$ \\
\hline Tenure & $\begin{array}{c}-0.001 \\
(0.31)\end{array}$ & $\begin{array}{l}-0.003 \\
(0.71)^{*}\end{array}$ & $\begin{array}{l}0.000 \\
(1.32)^{*}\end{array}$ \\
\hline Public & $\begin{array}{l}0.000 \\
(0.42)\end{array}$ & $\begin{array}{l}0.002 \\
(1.57)\end{array}$ & $\begin{array}{c}-0.000 \\
(0.24)\end{array}$ \\
\hline
\end{tabular}

Robust z-statistics in parentheses; ${ }^{* * *}$ significant at the $1 \%$ level; ${ }^{* *}$ significant at the $5 \%$ level; * significant at the $10 \%$ level; (no star) statistically insignificant 
Interestingly, the openness of the economy, measured by the trade index, has a reverse impact for the elderly when compared to the whole population. The higher the trade openness index, the lower the employment rate of the elderly and the higher the unemployment rate. In addition, the inflow of FDI also decreases the employment rate of the elderly. The results confirm that with the inflow of new technologies, a negative effect on the labor market might be expected in the short-run. The reasons for this might lay in frictional unemployment, which is associated with the reallocation of workers across sectors, or the skill gaps that exist between the labor supply of the elderly and labor demand imposed by the introduction of new occupations. Again, the results confirm that the elderly might be perceived as less attractive in the labor market when considering their ability and willingness to become fast learners and to participate in life-long learning activities. ${ }^{46}$

The higher the percentage of the highly educated among the elderly, the lower the unemployment rate and the higher the employment rate. The same relation is observed when estimating the impact of the percentage of people employed on a permanent contract.

The impact of policies affecting social harmonization is statistically significant and has a negative effect on the performance of the elderly in the labor market. An increase in PIT or SSC decreases the employment rate of the elderly and increases unemployment and inactivity rates. The negative impact of PIT and SSC increases is observed during the next two years after the implementation of the reform. It underlines the long-lasting effect of the reform on the performance of the elderly in the labor market.

These results are in line with other research findings on similar topics. In the last EU report on tax reforms, ${ }^{47}$ it was proven that higher labor taxes have a detrimental effect on vulnerable groups, which causes their exclusion from the labor market and, consequently, social inequality. The results prove once again that the more elastic the labor supply curve is, the more harmful the introduction of upward social convergence is for labor market outcomes. As found in other studies, ${ }^{48}$ the elderly are a group that is particularly responsive to changes in taxes.

\footnotetext{
46 MOPACT, 2016

47 European Commission (2014)

48 Siebertova, Z. et al. (2014)
} 


\section{Conclusions and policy recommendations}

The aim of this paper was to assess the relation between selected elements of the social harmonization policy and the employment, unemployment, and inactivity rates in the EU during the years 2000-2012 by using an Arellano-Bond dynamic panel data regression model.

The main results of the study identified that the impact of changes in PIT and SSC on unemployment, employment, and inactivity rates was, in the majority of cases, statistically insignificant for the whole working population. In cases when it was significant, the impact was weak. The variables that significantly affected labor market outcomes at the EU level were related to market performance, trade openness, FDI inflow, and education level of the population.

The impact of upward social harmonization differed for the population aged 50+. It was statistically significant and had a negative effect on the performance of the elderly in the labor market. An increase in PIT or SSC decreased the employment rate of the elderly and increased unemployment or inactivity rates. The negative impact of PIT and SSC increases was observed during the next two years after the implementation of the reform. This underlined the long-lasting effect of the reform on the performance of the elderly in the labor market.

Other variables that were also significant for labor market performance among the elderly were related to market performance, trade openness, FDI inflow, the education level of the population, as well as the share of people employed on a permanent contract.

In summary, changes in taxation, aimed at delivering the social harmonization of labor taxes, played a minor role in determining the outcomes of the labor market on the whole population. However, they had a significant impact on specific groups of people, like the elderly, who were more at risk of being dismissed or who were less likely to work once reaching the retirement age. With the aging of the European population and the European attempts to increase the employability of the elderly, the introduction of upward social harmonization might have a destructive effect on the measures undertaken in order to improve the situation of the elderly. 
Our policy recommendations are as follows. As the EC has already started to encourage tax reductions on labor, the EU should continue its trend of reducing the tax wedge, and, instead of aiming at upward social convergence, should revise the level of social convergence needed to maintain employment growth and decrease unemployment and inactivity rates.

In addition, when developing social harmonization within Europe, policy makers should pay special attention to the elderly and, in general, to the groups of people whose labor market participation strongly depends on their marginal tax rates.

To conclude, the findings of this paper are, in general, in line with previous empirical research, as empirical estimates confirm the effect of upward social harmonization on employment growth. In addition, the study confirms that the disfavored groups are much more at risk of any changes in the tax wedge than other groups. Therefore, labor market policies aimed to boost employment should concentrate on increasing marginal gains to work, especially for the elderly. It is also important to acknowledge the limitations of these findings, due to the limited time series, possible omitted variables unaccounted for in our estimation, and the relatively small variation among key variables. 


\section{References}

Andreica, M.E., Aparaschivei, L., Cristescu, A. and N. Cataniciu, (2010), Models of the Minimum Wage Impact upon Employment, Wages and Prices: The Romanian Case, Recent Advances in Mathematics and Computers in Business, Economics, Biology \& Chemistry, Bucharest

CEPS, (2016), Labour Mobility in the EU. Addressing challenges and ensuring 'fair mobility.', No. 139, July 2016, CEPS Special Report, Brussels, retrieved from https://www.ceps.eu/ system/files/SR139\%20MB\%20and\%20MB\%20LabourMobility.pdf

Cristescu, A., Popescu, M. E. and L. Stanila, (2016), Labour Tax effects on Labour Market outcomes in the European Union, Journal of Economic Studies and Research, Vol. 2016, retrieved from http://ibimapublishing.com/articles/JESR/2016/885330/

Dimian, G.C., Ileanu, B., Jablonsky, J. and J. Fabry, (2013), Analysis of European Labour Market in the Crisis Context, Prague Economic Papers, University of Economics, Prague, 2013(1)

Dolenc, P. and S. Laporsek, (2010), Tax Wedge on labour and its effect on employment growth in the European Union, Prague Economic Papers, 4.

Daveri, F. and G. Tabellini, (2000), Unemployment, growth and taxation in industrial countries, Economic Policy, Vol. 15 (30).

DG for Employment, Social Affairs and Inclusion, (2016), Study on wage setting systems and minimum rates of pay applicable to posted workers in accordance with Directive 96/71/ EC in a selected number of Member States and sectors, Contract No VC/2015/0334, Final report, European Commission, Brussels, retrieved from ec.europa.eu/social/BlobServlet?docld $=14965$ \&langld $=e n$

DG TAXUD, (2011), Tax reforms in EU Member States 2011. Tax policy challenges for economic growth and fiscal sustainability, Working paper no. 28-2011, European Commission, Brussels, retrieved from https://ec.europa.eu/taxation_customs/sites/taxation/files/resources/documents/taxation/gen_info/economic_analysis/tax_papers/taxation_paper_28_en.pdf

DG TAXUD, (2015), Tax Reforms in EU Member States: 2015 Report, Taxation Papers, Working Paper no. 58-2015, European Commission, Brussels, retrieved from https://ec.europa.eu/ taxation_customs/sites/taxation/files/docs/body/taxation_paper_58.pdf 
Drive Europe News, (2016), France: Minimum Wage for Foreign Truck Drivers - Hybrid Adventure, retrieved from https://driveeurope.co.uk/2015/02/17/hybrid-adventure/

Eichhorst, W., Marx, P., Wehner, C., (2016), Labor market reforms in Europe - towards more flexicure labor markets?, Discussion Paper Series, IZA DP No. 9863, retrieved from http://ftp.iza.org/dp9863.pdf

EUobserver, (2016), EU shown yellow card on workers' pay, Aleksandra Eriksson, Social Affairs, Brussels, retrieved from https://euobserver.com/social/133395

Euractiv, (2016), Employers' Chief: Juncker won't admit he is wrong on Posted Workers Directive, Lucie Bednarova, retrieved from https://www.euractiv.com/section/social-europe-jobs/interview/german-employers-chief-we-are-against-the-posted-workers-directive-revision/

European Commission, (2011), The role and impact of labour taxation policies, Universita Bocconi - Econpubblica - Centre for Research on the Public Sector, Milan

European Commission, (2014), Tax Reforms in EU Member States 2014. Tax policy challenges for economic growth and fiscal sustainability, European Economy, 6/2014, Brussels, retrieved from http://ec.europa.eu/economy_finance/publications/european_economy/2014/pdf/ee6 _en.pdf

European Commission, (2015a), College holds orientation debate on the economic and social dimension of the Single Market. Press release, Press Release Database, Strasbourg, retrieved from http://europa.eu/rapid/press-release_IP-15-5763_en.htm

European Commission, (2015b), Corporate Income Taxation in the European Union, Commission Staff Working Document, $\operatorname{COM(2015)} 302$ final, Brussels, retrieved from http://ec.europa.eu/taxation_customs/sites/taxation/files/resources/documents/taxation/ company_tax/fairer_corporate_taxation/swd_2015_121.pdf

European Commission, (2016), The Commission presents reform of posting of workers - towards a fair and truly European Labour Market, Employment, Social Affairs \& Inclusion, retrieved from http://ec.europa.eu/social/main.jsp?langld=en\&catld=89\&newsld=2488\&furtherNews =yes 
European Parliament, (2016), Legislative Train Schedule. Labour Mobility Package, retrieved from http://www.europarl.europa.eu/legislative-train/theme-deeper-and-fairer-internal-market -with-a-strengthened-industrial-base-labour/package-labour-mobility-package

European Political Strategy Center, (2015), The Social Dimension of Economic and Monetary Union. Towards Convergence and Resilience, EPSC Strategic Notes, Issue 5/2015, 18 June, European Commission, retrieved from https://ec.europa.eu/epsc/sites/epsc/files/strategic_note_issue_5.pdf

European Trade Union, (2015), Targeted review of the Posting of Workers Directive, Brussels, retrieved from https://www.etuc.org/sites/www.etuc.org/files/circular/files/target_review _pwd_etuc_contribution.pdf

European Trade Union, (2016), Free movement yes, social dumping, no!, Brussels, retrieved from https://www.etuc.org/sites/www.etuc.org/files/publication/files/flyer_social_dumping _en_06.pdf

EuVisions, (2016), The challenges of the European social model: An interview with Elsa Fornero, Giovanni Pagano, retrieved from http://www.euvisions.eu/the-challenges-of-the-european-social-model-an-interview-with-elsa-fornero/

Grand Duchy of Luxembourg, (2015), Presidency of the Council of the European Union, "Triple A social' meeting - Restoring the social dimension to the heart of European policy, retrieved from http://www.eu2015lu.eu/en/actualites/articles-actualite/2015/10/19-reunion-triple-a -social/index.html

Heyes, J., Hastings, T., (2016), Where now for flexicurity? Comparing post-crisis labour market policy changes in the European Union., SPERI Global Political Economy Brief no. 3, Sheffield Political Economy Research Institute, Sheffield, retrieved from http://speri.dept.shef.ac.uk/ wp-content/uploads/2016/03/Global-Brief-3-Where-now-for-flexicurity.pdf

Hurlin, C., (2010), Chapter 2. Dynamic panel data models, Universite d'Orleans, retrieved from http://www.univ-orleans.fr/deg/masters/ESA/CH/Geneve_Chapitre2.pdf 
Independent, (2017), Marine Le Pen pledges to introduce tax on French employment contracts for foreigners, Lizzie Dearden, retrieved from http://www.independent.co.uk/news/world/ europe/marine-le-pen-elections-france-president-latest-employment-contract-tax-foreigners-national-priority-a7559121.html

Konfederacja Lewiatan, (2016), Rewizja dyrektywy ws. Delegowania pracowników nie jest potrzebna - list do Komisarz Bieńkowskiej, Aktualności Bruksela, retrieved from http:// konfederacjalewiatan.pl/legislacja/lewiatan-w-brukseli/aktualnosci-bruksela/2016/1/rewizja_dyrektywy_ws_delegowania_pracownikow_nie_jest_potrzebna__list_do_komisarz_ bienkowskiej

Labour Market Reforms Database, retrieved from https://webgate.ec.europa.eu/labref/ public/result.cfm

McClelland, R. and S. Mok, (2012), A review of Recent Research on Labour Supply Elasticities, Working Paper Series, Congressional Budget Office retrieved from https://www.cbo. gov/sites/default/files/112th-congress-2011-2012/workingpaper/10-25-2012-Recent_Research_on_Labor_Supply_Elasticities_0.pdf

MOPACT, (2016), Mobilising the potential of active ageing in Europe, FP7 project, retrieved from http://mopact.group.shef.ac.uk/about/project-team/

NEUJOBS, (2011), Creating and Adapting jobs in Europe in the context of a socio-ecological transition, FP7 project, retrieved from http://www.neujobs.eu/

OECD (2016), Priorities for completing the European Union's Single Market. Jan Strasky, Economic Department Working Papers No. 1315, ECO/WKP (2016)39, Economic Department, Paris, retrieved from http://www.oecd.org/eco/Priorities-for-completing-the-EuropeanUnion-s-Single-Market.pdf

OECD (2017), Tax wedge (indicator). doi: 10.1787/cea9eba3-en (Accessed on March 29, 2017).

Seyfried, W., (2011), Examining the relationship between employment, economic growth in the ten largest states, Southwestern Economic Review, Vol. 32 (1).

Siebertova, Z., Senaj, M., Svarda, N. and J. Valachyova (2014), To work or not to work? Estimates of labour supply elasticities, National Bank of Slovakia, Working paper 5/213. 
United Nations Conference on Trade and Development, retrieved from http://unctadstat. unctad.org/EN/

Vandenbroucke F. and D. Rinaldi, (2015), Social inequalities in Europe: the challenge of convergence and cohesion, Delors Institute, retrieved from http://www.delorsinstitute. eu/011-22215-Social-inequalities-in-Europe-the-challenge-of-convergence-and-cohesion. html

Vodopivec, M., (2004), Income support for the unemployed: issues and options, Washington DC, the World Bank.

Vork, A., Leetmaa, R., Paulus, A., and S. Anspal, (2007), Tax-benefit systems in the New Member States and their impact on labour supply and employment, Praxis Policy Paper, 29/2007. 


\section{Annexes}

\section{Annex 1}

Table A1: Minimum wages in the EU

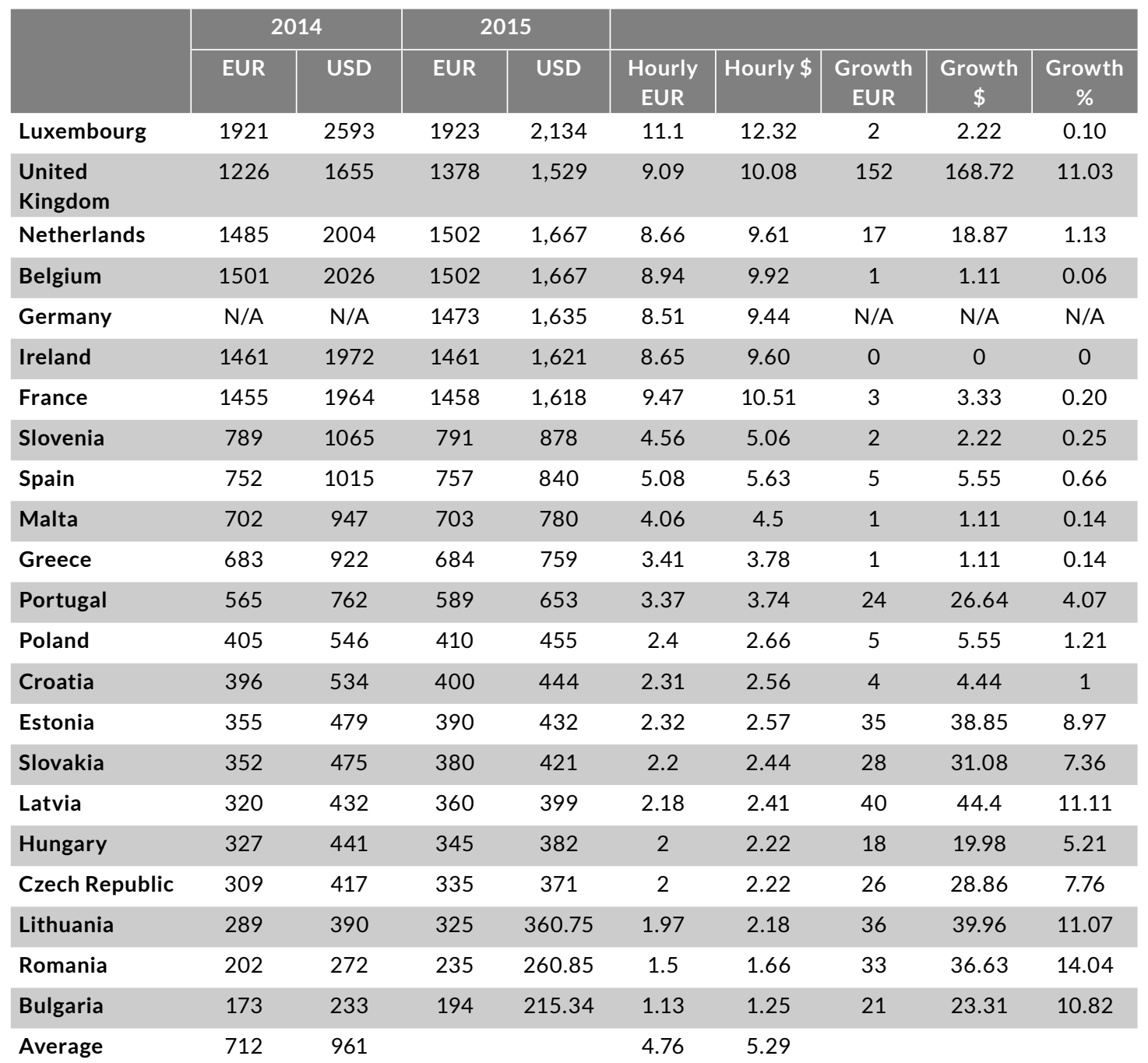

Source: Eurostat 
CASE Project Reports | Nr 487 (2017)

Table A2: Unemployment rate, inactive population, and employment rate for the population aged $15-64$ and 50+, 2015

\begin{tabular}{|c|c|c|c|c|c|c|}
\hline \multirow[b]{2}{*}{ GEO/AGE } & \multicolumn{2}{|c|}{ Unemployment rates (\%) } & \multicolumn{2}{|c|}{$\begin{array}{l}\text { Inactive population (\% } \\
\text { of total population) }\end{array}$} & \multicolumn{2}{|c|}{ Employment rates (\%) } \\
\hline & $15-64$ & $50-64$ & $15-64$ & $50-64$ & $15-64$ & $50-64$ \\
\hline EU 28 & 9,6 & 7,0 & 27,5 & 33,5 & 65,6 & 61,8 \\
\hline Belgium & 8,6 & 5,8 & 32,4 & 41,0 & 61,8 & 55,5 \\
\hline Bulgaria & 9,2 & 8,4 & 30,7 & 33,9 & 62,9 & 60,6 \\
\hline Czech Republic & 5,1 & 4,3 & 26,0 & 30,6 & 70,2 & 66,4 \\
\hline Denmark & 6,3 & 4,8 & 21,5 & 25,3 & 73,5 & 71,1 \\
\hline Germany & 4,7 & 4,3 & 22,4 & 23,7 & 74,0 & 73,0 \\
\hline Estonia & 6,3 & 6,1 & 23,3 & 24,4 & 71,9 & 71,0 \\
\hline Ireland & 9,6 & 7,6 & 30,0 & 33,3 & 63,3 & 61,6 \\
\hline Greece & 25,1 & 18,4 & 32,2 & 46,2 & 50,8 & 43,9 \\
\hline Spain & 22,2 & 18,7 & 25,7 & 33,3 & 57,8 & 54,2 \\
\hline France & 10,4 & 7,2 & 28,7 & 35,9 & 63,8 & 59,5 \\
\hline Croatia & 16,5 & 11,7 & 33,2 & 45,4 & 55,8 & 48,2 \\
\hline Italy & 12,1 & 6,4 & 36,0 & 39,9 & 56,3 & 56,3 \\
\hline Cyprus & 15,2 & 14,3 & 26,1 & 33,5 & 62,7 & 57,0 \\
\hline Latvia & 10,1 & 9,7 & 24,3 & 28,2 & 68,1 & 64,8 \\
\hline Lithuania & 9,3 & 8,8 & 25,9 & 26,0 & 67,2 & 67,5 \\
\hline Luxembourg & 6,7 & 5,1 & 29,1 & 44,3 & 66,1 & 52,8 \\
\hline Hungary & 6,8 & 5,8 & 31,4 & 40,8 & 63,9 & 55,8 \\
\hline Malta & 5,5 & 4,4 & 32,4 & 48,7 & 63,9 & 49,1 \\
\hline Netherlands & 6,9 & 7,2 & 20,4 & 26,7 & 74,1 & 68,0 \\
\hline Austria & 5,8 & 4,4 & 24,5 & 37,1 & 71,1 & 60,2 \\
\hline Poland & 7,6 & 5,8 & 31,9 & 43,6 & 62,9 & 53,2 \\
\hline Portugal & 12,9 & 11,5 & 26,6 & 33,9 & 63,9 & 58,5 \\
\hline Romania & 7,0 & 4,3 & 33,9 & 47,8 & 61,4 & 50,0 \\
\hline Slovenia & 9,1 & 7,6 & 28,2 & 44,6 & 65,2 & 51,2 \\
\hline Slovakia & 11,5 & 9,9 & 29,1 & 36,4 & 62,7 & 57,3 \\
\hline Finland & 9,6 & 7,7 & 24,2 & 27,1 & 68,5 & 67,3 \\
\hline Sweden & 7,6 & 5,1 & 18,3 & 17,4 & 75,5 & 78,3 \\
\hline $\begin{array}{l}\text { United } \\
\text { Kingdom }\end{array}$ & 5,4 & 3,4 & 23,1 & 27,9 & 72,7 & 69,6 \\
\hline
\end{tabular}

Source: Eurostat 


\section{Annex 2}

Chart A1: Tax wedge in EU/OECD countries, 2015 (total, \% of labor costs)

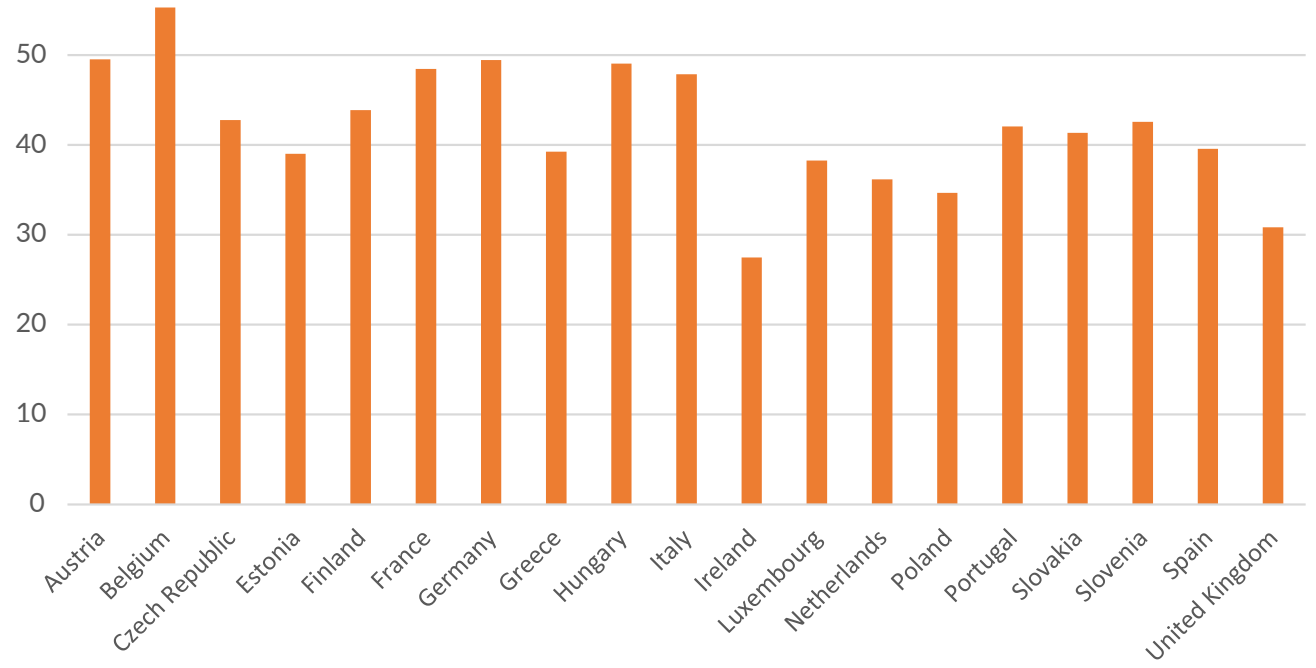

Source: OECD

Chart A2: Tax wedge level (as \% of total labor cost) on low-wage earners (i.e. single persons without children earning $67 \%$ of the average wage), 2015

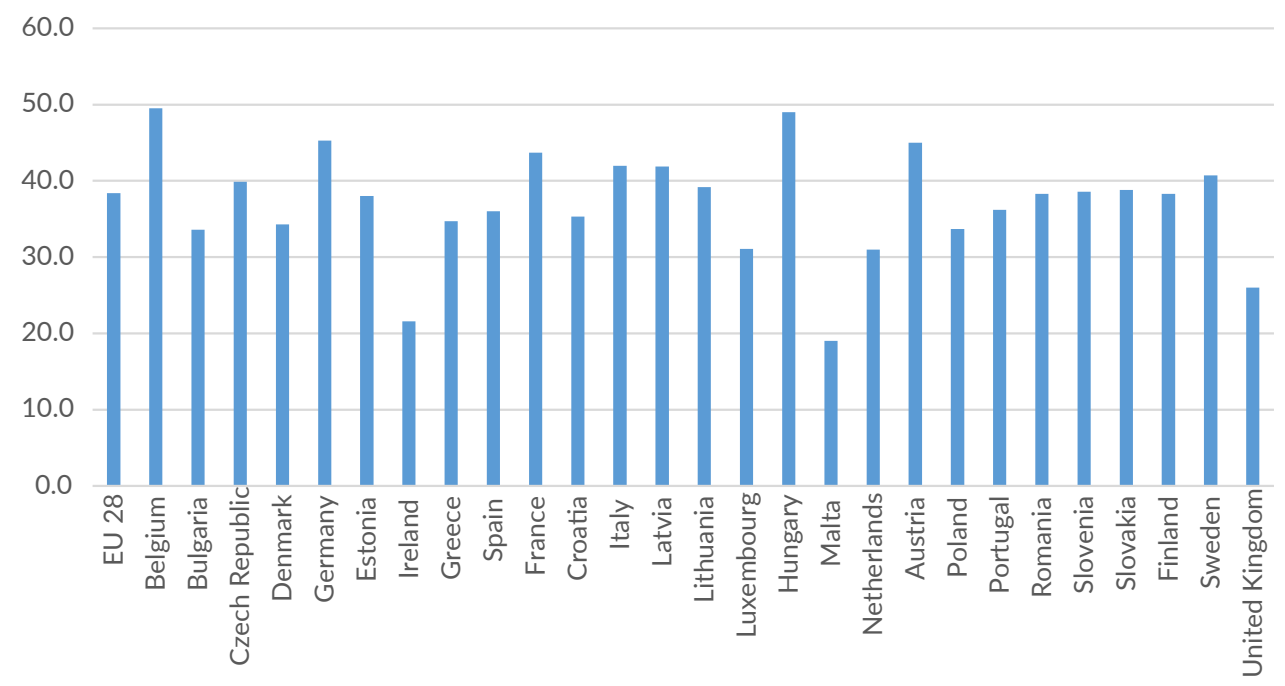

Source: Eurostat 
Chart A3: Ratio of minimum relative to average wages of full-time workers, 2015

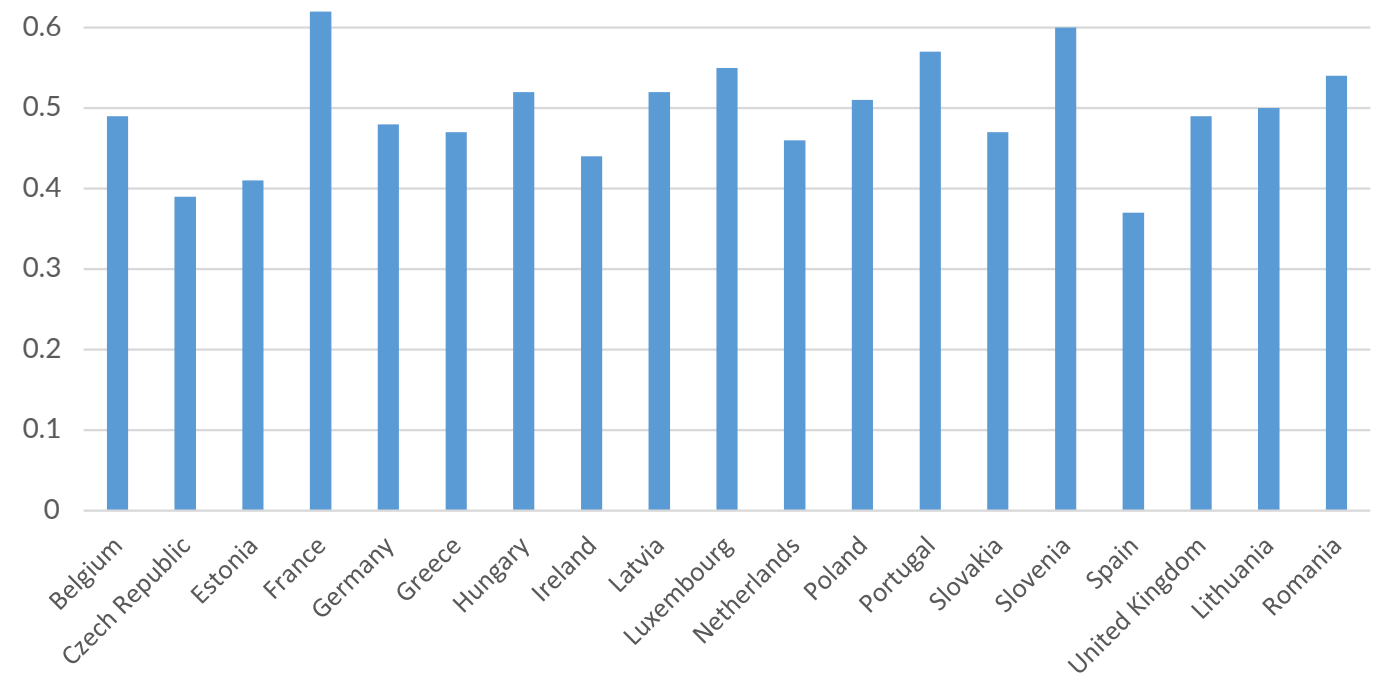

Source: OECD

Chart A4: Median gross hourly earnings and purchasing power standard, all employees (excluding apprentices), 2014

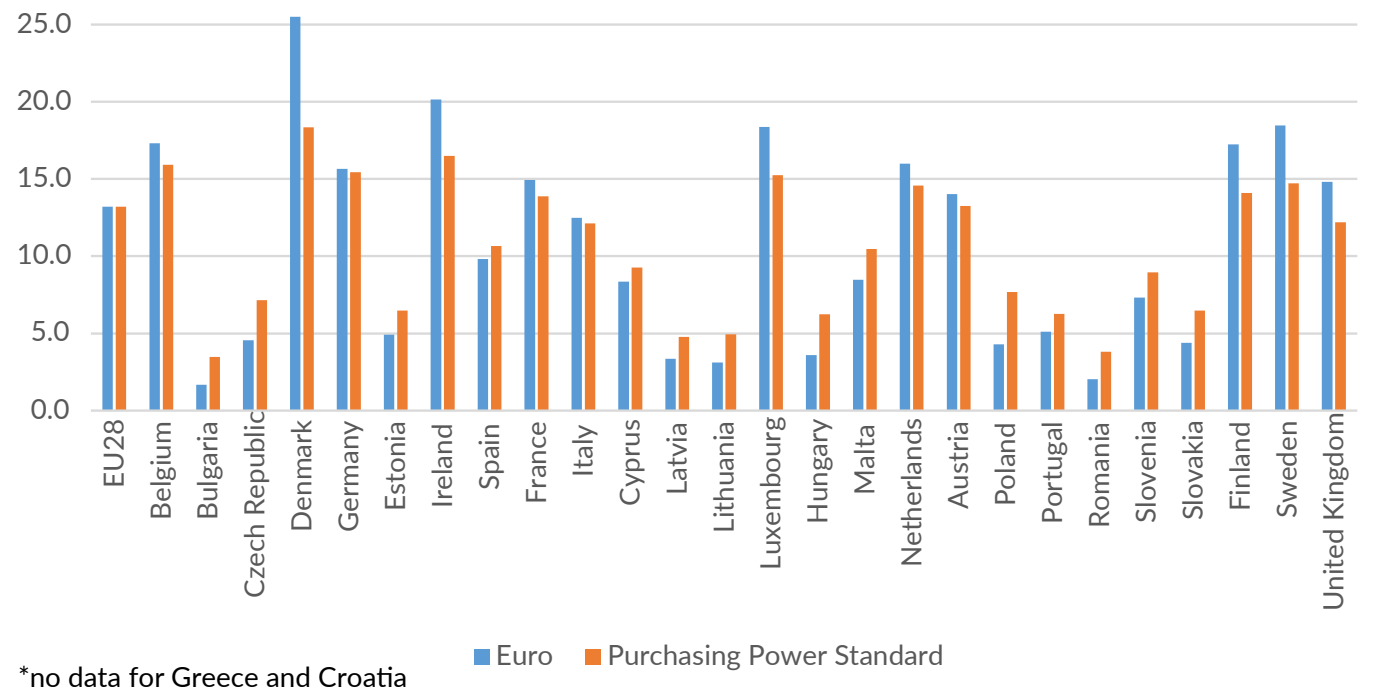

Source: Eurostat 
Chart A5: Expenditure on social protection in purchasing power standard per inhabitant in the EU, 2014

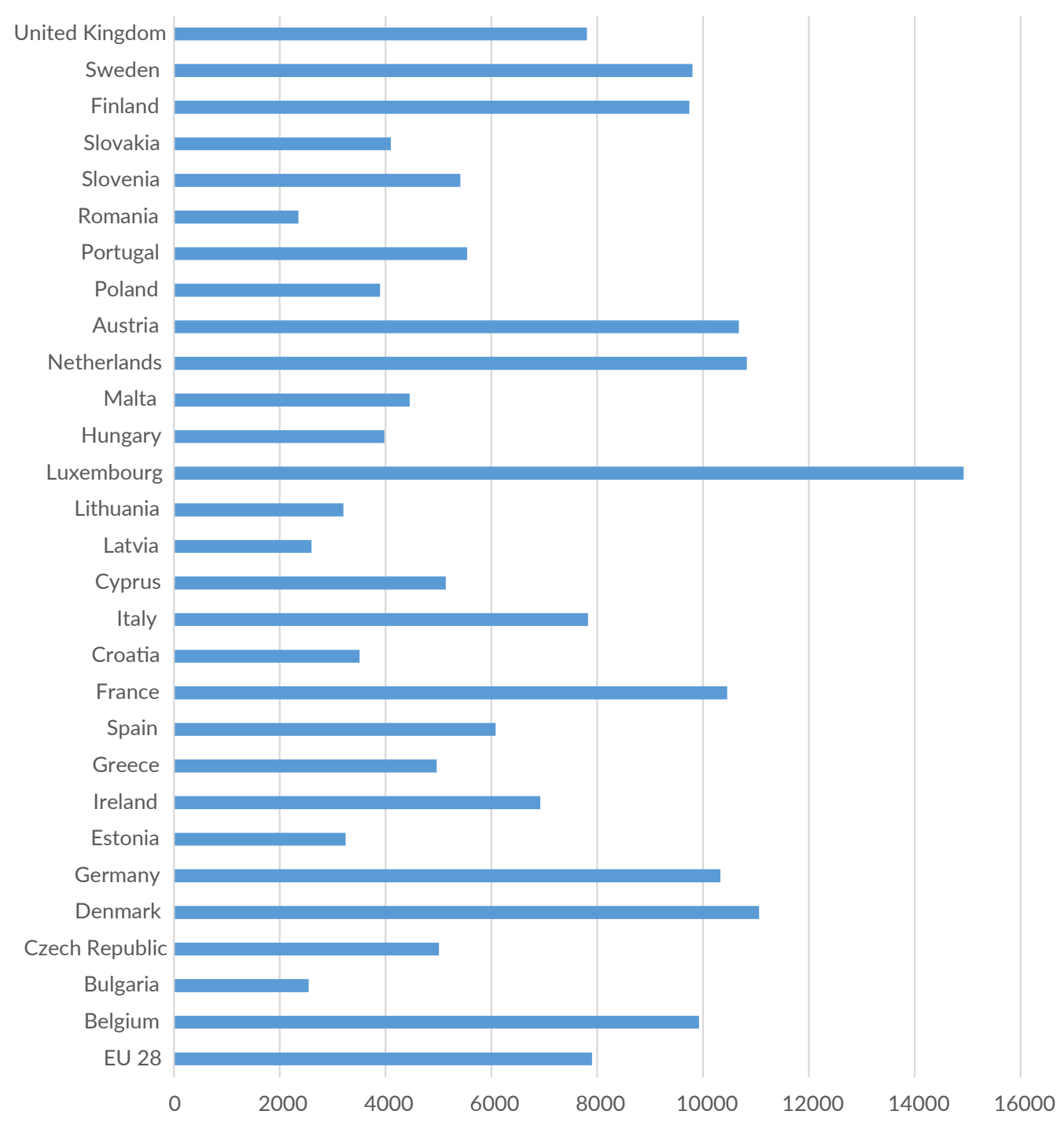

Source: Eurostat 
Chart A6: Expenditure on social protection as a \% of GDP, 2014

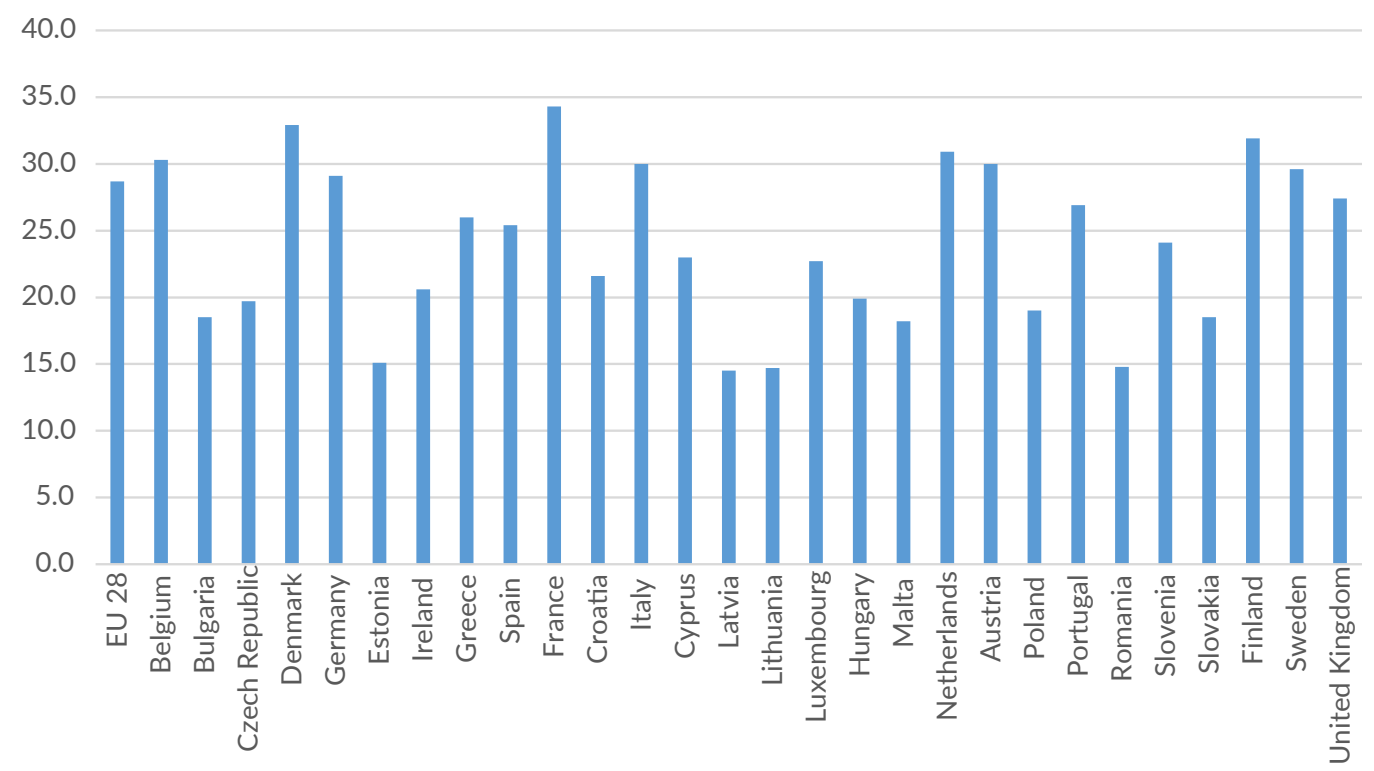

Source: Eurostat 
Chart A7: Total receipts from taxes and social contributions (including imputed social contributions) after deduction of amounts assessed but unlikely to be collected, 2015

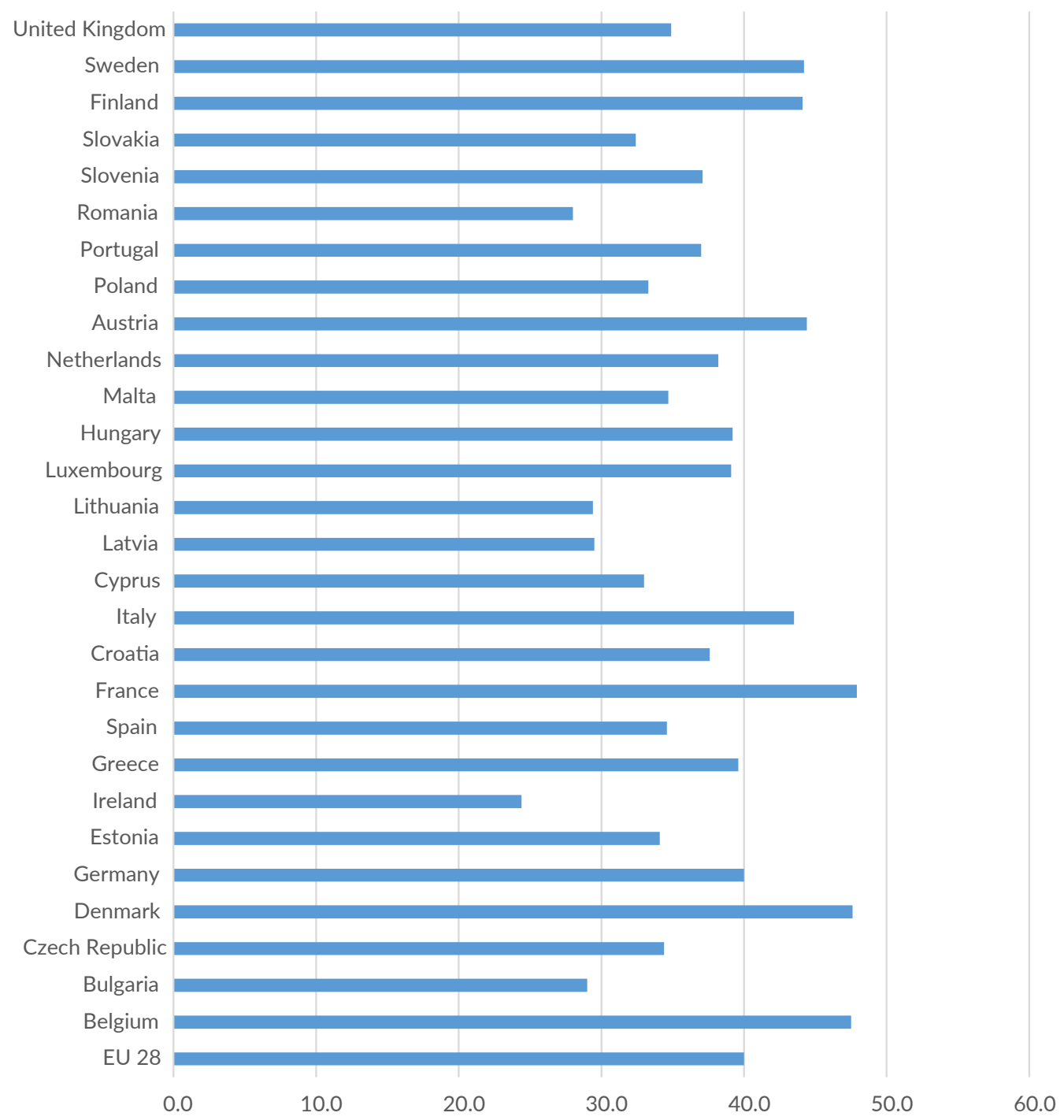

Source: Eurostat 